Volume 15 Issue 1 Year: 2018

\title{
Examination of the effects of some variables in internal control and organizational stress management via multiple regression on perception of risk and uncertainty
}

\author{
İlknur Bilgen ${ }^{1}$ \\ Hikmet Yaşar $^{2}$ \\ Mustafa Şeker ${ }^{3}$ \\ Nuh Mehmet Büyüksivaslığlu ${ }^{4}$
}

\begin{abstract}
Internal control is an essential element of successful and effective management. Internal control which plays a role as a proactive and integral element in organizations' adapting to changing and changes also plays an important role in the realization of organizational strategy. In some cases, change brings risks along with uncertainties. One of the most effective tools against the stress occurring in cases where the risks and change cannot be managed is, without doubt, internal control practices. Risk management practices are dealt with within the scope of internal control. Risk management is directly related to perception of risks and uncertainties of the employees and the organization. The effect of some variables on the perception of risk and uncertainty has been investigated since the risks and uncertainties in the organizations are constantly in interaction with stress and internal control applications. The study was conducted face to face by asking 348 entrepreneurs operating on the textile industry to fill in the survey form in Kayseri in Turkey. The effects of total work experience, age, gender and strength on perception of risk and uncertainty have been determined.
\end{abstract}

Keywords: Internal control, organizational stress, perception of risk and uncertainty, meaningful work, flexibility.

\section{Introduction}

In today's business world, even small sized firms are responsible for transparency and accountability as well as big ones. Due to the evaluation of accounting systems all over the world, almost all companies worldwide started to control their activities by inner mechanisms. Internal control is playing a key role in companies' main strategic decisions moreover their missions and visions. Organizational stress is another factor examined in this study. It is clear that there are variously stress sources in individuals' lives and business area seems to be one of them. Perception of risk and uncertainty tend to be higher when control mechanisms are week and organizational stress is high. In this study, effects between these instruments are examined via multiple regression analysis.

\footnotetext{
${ }^{1}$ Assist. Prof., Hakkari University, Hakkari, Turkey, ilknurbilgen@hakkari.edu.tr

2 Instructor, Hakkari University, Çölemerik MYO, Hakkari, Turkey, hikmetyasar30@gmail.com

${ }^{3} \mathrm{PhD}$. Student, Near East University, Institute of Social Sciences, Lefkosa, Cyprus, mstfseker@gmail.com

${ }^{4} \mathrm{PhD}$. Student, Southern University (IMBL), Rostov on Don, Russia, nuhmbs@gmail.com
} 
Bilgen, İ., Yaşar, H., Şeker, M., \& Büyüksivaslığlu, M. N. (2018). Examination of the effects of some variables in internal control and organizational stress management via multiple regression on perception of risk and uncertainty. Journal of Human Sciences, 15(1), 155-162. doi:10.14687/jhs.v15i1.4919

\section{Literature Review}

According to the Institute of Internal Control Auditors, internal control is defined as: An activity performed by the management in order to increase the likelihood of the realization of the objectives which have been planned before.

As Bilgi, Mihaylova and Papazov mentioned, internal control is a system which is related with the others in business that all of the staff is responsible for but still managers are seem to be the leaders in this system (Bilgi, Mihaylova and Papazov, 2017). Management is required to certify thet their internal controls are well designed and operating effectively (Dickins and Fay, 2017).

Internal control is broadly defined by The Committee of Sponsoring Organizations of the Treadway Commission (COSO) as a process, effected by an entity's board of directors, management, and other personnel, designed to provide reasonable assurance regarding the achievement of strategic goals relating to operations, reliability of financial reporting, designed to enable to trust in obtaining the objectives in compliance with laws, regulations and policies to be obeyed (Yilanci, 2003). The COSO internal control structure with its specific components (control environment, risk assessment, control activities, information and communication, monitoring activities) has come into existence as a multidimensional structure that ensures effectiveness

and efficiency of operating activities, it guarantees information reliability of financial reports offered by the company and does not conflict with existing legislation (Türedi and Karakaya, 2015). Internal control helps an institution reach its performance and profitability objectives as well as being protected against the risk of loss. For a sound and effective organizational structure, it is necessary that internal control is designed, and operated professionally (Akyel, 2010).

Risks arising from within and outside institutions may stem from the changes around the activities, new staff, renewal or replacement of the information system, rapid growth, new technologies, new products and activities, reconstruction of the institution, overseas operations, the adoption or changing of new accounting principles (Hall, 2004).

Organizational stress literature is growing by the time while it is critical for organizational performance (Rumbold, Fletcher and Daniels, 2018). Organizations face many different problems while managing processes, such as organizational stress (Özdemir Yaylac1, 2005). In organizational stress, the sources of stress and the state of tension in a business atmosphere (Maureen et al, 2001) as well as indicating characteristics of a job and harmful effects of work-related socio-psychological situations on individuals (Behr, 1998). Due to the authors interested in European countries, work place has a meaningful effect on men's mental health (Bossmann, Ditzen and Schweitzer, 2016; Yankovskaya et al, 2017)). There is a similar situation in USA that organizational stress damages people physically (Cranwell-Ward and Abbey, 2005). Basic sources of organizational stress are rumors arising in situations of uncertainty in workplaces, conflicts, behaviors directed towards violence or discrimination (Bordia et al, 2006), ambiguity and/or role conflicts that are observed where there is a chaos of power and responsibility (Christine, 2003). The hot spots can be classified as; job demands, control at work, support at work, workplace relationships, role-based stress and changes to the job and the organization (Weinberg, Sutherland and Cooper, 2010).

Different from other positive psychological capital components, "sturdiness" having a more reactive nature is defined as positive adaptation of an individual to the circumstances under specific risks and adverse condition (Masten and Reed, 2002) to be robust for the problems and difficulties, and to be able to recuperate (Avey, Wernsing and Luthans, 2008). The workers with high flexibility do not have difficulty in adapting to the conditions of competitive, variable and uncertain work environment. (Akcay, 2012).

Although there is not a common idea what its nature and components are, meaningful work is a concept which is very attractive for researchers (Steger et al., 2012). It can be defined as the positive and important contribution of a work to individuals' meaningfulness of life besides individuals' having pleasure from their work (Rosso, Dekas and Wrzesniewski, 2010). 
Bilgen, İ., Yaşar, H., Şeker, M., \& Büyüksivaslığlu, M. N. (2018). Examination of the effects of some variables in internal control and organizational stress management via multiple regression on perception of risk and uncertainty. Journal of Human Sciences, 15(1), 155-162. doi:10.14687/ihs.v15i1.4919

Meaningful work could be said to have three primary aspects: (1) Psychological Meaningfulness at work, how significant the work is for the employees (2) Making meaning via work: understanding the meaning of life linking with a meaningful work; (3) Greater good motivations: The need to make a positive impact on the greater good for especially others (Steger et al., 2012).

The concept of risk bears the probability of occurrence of various possibilities in connection with a threat. It is based on the distinction between reality and possibility in this respect. The validity of the concept disappears in the cases where possibilities disappear or get out of the individual initiatives. In other words, the risk is about how the individual or the society defines themselves in coping with the change and the future. (Furedi, 2001). The main players able to influence risk control in an organization are; the board or a similar leadership committee, risk control managers, internal audit managers, line managers, IT managers and everyone else in the organization (Leitch, 2008). The researches show that such factors as age, income and education level are active in "taking risks" besides the personal characteristics like the ability to predict the future and adventurism (Sung and Hanna, 1997).

\section{Method}

The research was conducted in order to find out how the employees in textile manufacturing sector got effected from such factors as flexible behaviors to perceptions of risk and uncertainty, gender, education level, age, total work experience and meaningful work through the method of relational survey. The universe of the survey is composed of the entrepreneurs in textile industry in Kayseri in Turkey. The sample of the survey consists of totally 348 people- chosen through convenience sampling method, $110(31,6 \%)$ of whom are women and $238(68,4 \%)$ of whom are men.

The survey form consists of the following means of measurement:

1. Demographic Data Form: Consist of questions related to age, gender, education level and total work experience.

2. Flexibility Scale: A 15-question scale, developed by Wagnild, GM Young, HM (1993).

Cronbach Alpha reliability coefficient of the scale was calculated as 0,829 .

3. Scale of Meaningful Work: A10-question scale adapted to Turkish by Ali, A., Hamedoğlu, M.,

Kumar, MP., And Pine, H. (2013). Cronbach Alpha reliability coefficient of the scale was calculated as 0,891 .

4- Perception of Risk and Uncertainty Scale: Perception of risk and uncertainty scale developed by Bozkurt, Veysel and Baştürk (2009) is consisted of 6 questions. Cronbach Alpha reliability coefficient of the scale was calculated as 0,707.

For all scales, confirmatory factor analysis is performed by benefitting from Statistical Package of the Social Sciences (SPSS) and Analysis of Moment Structures (AMOS) 23.0 and the fit indices those were obtained from the analysis were shown in table 1.

Table 1: Fit indexes of scales

\begin{tabular}{|l|c|c|c|c|c|}
\hline \multicolumn{1}{|c|}{ Fit Measure } & Good Fit & Acceptable Fit & Flexibility & $\begin{array}{c}\text { Meaningful } \\
\text { Work }\end{array}$ & $\begin{array}{c}\text { Perception of } \\
\text { Risk and } \\
\text { Uncertainty }\end{array}$ \\
\hline$\chi 2 /$ df &, $0 \leq \chi^{2 / \mathrm{df} \leq 2,0}$ & $2 \leq \chi^{2 / \mathrm{df} \leq 3}$ & 2,611 & 1,170 & 1,428 \\
\hline RMSEA &, $0 \leq \mathrm{RMSEA} \leq, 05$ &, $0 \leq \mathrm{RMSEA} \leq, 08$ &, 068 &, 022 &, 035 \\
\hline NFI & $, 95 \leq \mathrm{NFI} \leq 1,00$ &, $90 \leq \mathrm{NFI} \leq, 95$ &, 987 &, 989 &, 966 \\
\hline RFI & $, 90<\mathrm{RFI} \leq 1,00$ &, $85<\mathrm{RFI} \leq, 90$ &, 968 &, 973 &, 927 \\
\hline IFI & $, 95 \leq \mathrm{IFI} \leq 1,00$ &, $90 \leq \mathrm{IFI} \leq, 95$ &, 992 &, 998 &, 990 \\
\hline TLI & $, 95 \leq \mathrm{TLI} \leq 1,00$ &, $90 \leq \mathrm{TLI} \leq, 95$ &, 980 &, 996 &, 977 \\
\hline CFI & $, 97 \leq \mathrm{CFI} \leq 1,00$ &, $95 \leq \mathrm{CFI} \leq, 97$ &, 992 &, 998 &, 989 \\
\hline HOELTER & \multicolumn{2}{|c|}{$>200$} & 316 & 471 & 489 \\
\hline
\end{tabular}


Bilgen, İ., Yaşar, H., Şeker, M., \& Büyüksivaslığlu, M. N. (2018). Examination of the effects of some variables in internal control and organizational stress management via multiple regression on perception of risk and uncertainty. Journal of Human Sciences, 15(1), 155-162. doi:10.14687/ihs.v15i1.4919

Root Mean Square Error of Approximation (RMESA), Normed Fit Index (NFI), Relative Fit Index (RFI), Incremental Fit Index (IFI), Tucker-Lewis Index (TLI), Comparative Fit Index (CFI), Holter's critical value (HOELTER) and p-value for H0 (PCLOSE) rates have been examined. NFI, is positively related with the number of Sampling. NFI, RFI, IFI, TLI and CFI rates between 0,00 and 1,00. If model rates between 0,05 and 0,08 RMESA, it can be regarded as an acceptable harmony. The limit values for coherence indexes are shown in Table 1. (Hair vd., 2010; Bayram, 2010: 75-76).

When the table- 1 is examined above, it is seen that the analysis rates are of a relative agreement or acceptable limits.

\section{Findings}

Descriptive statistics related to demographic data of the employees participating in the study are shown in Table 2.

Table 2: Descriptive statistics on demographic data

\begin{tabular}{|c|c|c|c|c|c|}
\hline age & Frequency & Percent & Experience & Frequency & Percent \\
\hline $18-30$ & 133 & 38,2 & $1-5$ years & 163 & 46,8 \\
\hline $31-40$ & 154 & 44,3 & 6-10 years & 98 & 28,2 \\
\hline $41-50$ & 57 & 16,4 & $11-15$ years & 38 & 10,9 \\
\hline $51-60$ & 4 & 1,1 & $16-20$ years & 32 & 9,2 \\
\hline Total & 348 & 100,0 & 21 years and over & 17 & 4,9 \\
\hline education & Frequency & Percent & Total & 348 & 100,0 \\
\hline Secondary-high & 51 & 14,7 & Gender & Frequency & Percent \\
\hline High school & 18 & 5,2 & Woman & 110 & 31,6 \\
\hline Faculty & 279 & 80,2 & Man & 238 & 68,4 \\
\hline Total & 348 & 100,0 & Total & 348 & 100,0 \\
\hline
\end{tabular}

It is clearly seen in the Table 2 that $31.6 \%$ of the respondents are women and $68.42 \%$ of them are men; the percentage of those who are graduates of a faculty is $80,2 \%$, which is rather a high one; the average age is 40 , which is also high, and less than 40 with the rate of $82,5 \%$ $(=38,2 \%+44,3 \%)$; their work experience in current workplace is less than 10 years with the rate of $75 \%(=46,8 \%+28,2 \%)$

Table 3: Model summary for multiple regression

\begin{tabular}{|c|c|c|c|c|c|c|c|c|c|}
\hline \multirow[b]{2}{*}{ Model } & \multirow[b]{2}{*}{$\mathrm{R}$} & \multirow[b]{2}{*}{$\begin{array}{c}\mathrm{R} \\
\text { Square }\end{array}$} & \multirow[b]{2}{*}{$\begin{array}{l}\text { Adjusted R } \\
\text { Square }\end{array}$} & \multirow[b]{2}{*}{$\begin{array}{l}\text { Std. Error of the } \\
\text { Estimate }\end{array}$} & \multicolumn{5}{|c|}{ Change Statistics } \\
\hline & & & & & $\begin{array}{l}\text { R Square } \\
\text { Change }\end{array}$ & $\begin{array}{c}\mathrm{F} \\
\text { Change }\end{array}$ & df1 & df2 & $\begin{array}{l}\text { Sig. F } \\
\text { Change }\end{array}$ \\
\hline 1 & ,406a & 165, & 155 & 1,131 &, 165 & 16,922 & 4 & 343 &, 000 \\
\hline 2 &, $454^{\mathrm{b}}$ & 206 & 192, & 1,106 & ,041 & 8,876 & 2 & 341 & 000 \\
\hline
\end{tabular}

a. Predictors: (Constant), gender, education level, age, total work experience

b. Predictors: (Constant), gender, education level, age, total work experience, sturdiness / flexibility, meaningful work

When Table 3 is examined, it can be seen that sig $\mathrm{F}$ change value for model 1 and model 2 is 0,000 ; model 2 has lower $\mathrm{R}$ square change $(0,041<0,165)$ and $\mathrm{f}$ change $(8,876<16,922)$ values with regard to model 1; however, it has higher values than model 1 in respect of $R(0,454>0,406), R$ square $(0,206>0,165)$ and adjusted $\mathrm{R}$ square $(0,192>0,155)$. 
Bilgen, İ., Yaşar, H., Șeker, M., \& Büyüksivaslıoğlu, M. N. (2018). Examination of the effects of some variables in internal control and organizational stress management via multiple regression on perception of risk and uncertainty. Journal of Human Sciences, 15(1), 155-162. doi:10.14687/ihs.v15i1.4919

Table 4: ANOVA* for multiple regression $^{\mathrm{a}}$

\begin{tabular}{|c|c|c|c|c|c|c|}
\hline & Model & Sum of Squares & df & Mean Square & $\mathrm{F}$ & $p$ \\
\hline \multirow{3}{*}{1} & Regression & 86,574 & 4 & 21,644 & \multirow{3}{*}{16,922} & \multirow{3}{*}{, $000^{b}$} \\
\hline & Residual & 438,701 & 343 & 1,279 & & \\
\hline & Total & 525,276 & 347 & & & \\
\hline \multirow{3}{*}{2} & Regression & 108,282 & 6 & 18,047 & \multirow{3}{*}{14,758} & \multirow{3}{*}{, $000^{c}$} \\
\hline & Residual & 416,994 & 341 & 1,223 & & \\
\hline & Total & 525,276 & 347 & & & \\
\hline
\end{tabular}

a. Dependent variable: Perception of Risk and Uncertainty

b. Predictors: (Constant), gender, education level, age, total work experience

c. Predictors: (Constant), gender, education level, age, total work experience, sturdiness / flexibility meaningful work

When the ANOVA analysis in Table 4 is examined, it is seen that models 1 and 2 have the same meaning level $(\mathrm{p}=0.000)$; $\mathrm{df}$ value of model 2 is higher than that of model $1(6>4)$, yet its $\mathrm{F}$ value is lower than that of model $1 \quad(14.758<16.922)$.

Table 5: Coefficients for multiple regression ${ }^{\mathrm{a}}$

\begin{tabular}{|c|c|c|c|c|c|}
\hline \multirow{2}{*}{ Model } & \multicolumn{2}{|c|}{ Unstandardized Coefficients } & \multirow{2}{*}{$\frac{\text { Standardized Coefficients }}{\text { Beta }}$} & \multirow{2}{*}{$\mathrm{t}$} & \multirow{2}{*}{$\mathrm{p}$} \\
\hline & $\mathrm{B}$ & Std. Error & & & \\
\hline (Constant) & 2,928 &, 313 & & 9,346 &, 000 \\
\hline Total work experience & ,310 & ,066 & ,297 & 4,692 & ,000 \\
\hline 1 Education level &,- 004 & ,061 &,- 004 &,- 071 & ,943 \\
\hline Age &,- 263 & ,104 &,- 159 & $-2,533$ & ,012 \\
\hline Gender & ,939 & ,131 &, 355 & 7,162 & 000 \\
\hline (Constant) & 1,593 &, 526 & & 3,029 & ,003 \\
\hline Total work experience & ,212 & 069 & 203 & 3,086 & ,002 \\
\hline Education level &,- 033 & 060 &,- 028 &,- 557 & ,578 \\
\hline 2 Age &,- 202 & 103 &,- 122 & $-1,965$ & ,049 \\
\hline Gender & ,922 & ,128 & 349 & 7,184 & ,000 \\
\hline Sturdiness/Flexibility & 023 & 083 & ,015 & ,273 & ,785 \\
\hline Meaningful work & 261 & ,073 & 212 & 3,571 & ,000 \\
\hline
\end{tabular}

Dependent Variable: Perception of Risk and Uncertainty

It is seen, when Table 5 is examined, that total work experience, age, gender and meaningful work meet the condition of $\mathrm{p}<0,05$ in model 2 and these variables have the same effects as $\mathrm{p}$ values to perception of risk and uncertainty.

Table 6: Multiple regression to the excluded variables ${ }^{\mathrm{a}}$

\begin{tabular}{|c|c|c|c|c|c|}
\hline \multirow[b]{2}{*}{ Model } & \multirow[b]{2}{*}{ Beta In } & \multirow[b]{2}{*}{$\mathrm{t}$} & \multirow[b]{2}{*}{$\mathrm{p}$} & \multirow[b]{2}{*}{ Partial Correlation } & \multirow{2}{*}{$\frac{\text { Collinearity Statistics }}{\text { Tolerance }}$} \\
\hline & & & & & \\
\hline Sturdiness/Flexibility &, $111^{\mathrm{b}}$ & 2,199 &, 029 & ,118 & ,943 \\
\hline Meaningful work & ,219b & 4,210 &, 000 & ,222 & ,856 \\
\hline
\end{tabular}

a. Dependent Variable: Perception of Risk and Uncertainty

b. Predictors in the model: (Constant), gender, education level, age, total work experience

In Table 6 it is observed that flexibility and meaningful work meet the condition of $\mathrm{p}<0.05$. When the values in Table 6 are evaluated along with those in Table 4, it can be said that there is a relation of sturdiness and flexibility but its effect is likely to be coincidental as seen in model 2 . The results of the analysis of the correlation carried out in order to research the detail of this relation is shown in Table 6. 
Bilgen, İ., Yaşar, H., Șeker, M., \& Büyüksivaslığlu, M. N. (2018). Examination of the effects of some variables in internal control and organizational stress management via multiple regression on perception of risk and uncertainty. Journal of Human Sciences, 15(1), 155-162. doi:10.14687/ihs.v15i1.4919

Table 7: Correlations

\begin{tabular}{|c|c|c|c|c|c|c|c|c|}
\hline & & 1 & 2 & 3 & 4 & 5 & 6 & 7 \\
\hline 1-age & $\begin{array}{l}\text { Pearson Correlation } \\
\mathrm{p}\end{array}$ & 1 & & & & & & \\
\hline 2-gender & $\begin{array}{l}\text { Pearson Correlation } \\
\mathrm{p}\end{array}$ & $\begin{array}{l}, 029 \\
, 588\end{array}$ & 1 & & & & & \\
\hline 3-education level & $\begin{array}{l}\text { Pearson Correlation } \\
\mathrm{p}\end{array}$ & \begin{tabular}{r|}
, $170^{* *}$ \\
, 001
\end{tabular} & $\begin{array}{r}-, 005 \\
, 930\end{array}$ & 1 & & & & \\
\hline 4-total work experience & $\begin{array}{l}\text { Pearson Correlation } \\
\mathrm{p}\end{array}$ & $\begin{array}{r}, 614^{* *} \\
, 000 \\
\end{array}$ & \begin{tabular}{r|}
,- 064 \\
, 235
\end{tabular} & $\begin{array}{r}193^{* *} \\
, 000\end{array}$ & 1 & & & \\
\hline $\begin{array}{l}\text { 5-Perception of risk and } \\
\text { uncertainty }\end{array}$ & $\begin{array}{l}\text { Pearson Correlation } \\
\mathrm{p}\end{array}$ & $\begin{array}{l}033 \\
, 544\end{array}$ & $\begin{array}{r}, 332^{* *} \\
, 000 \\
\end{array}$ & $\begin{array}{l}025 \\
, 644\end{array}$ & $\begin{array}{r}, 176^{* *} \\
, 001 \\
\end{array}$ & 1 & & \\
\hline 6-Sturdiness/Flexibility & $\begin{array}{l}\text { Pearson Correlation } \\
\mathrm{p}\end{array}$ & $\begin{array}{l}040 \\
, 456\end{array}$ & $\begin{array}{l}, 003 \\
, 960\end{array}$ & $\begin{array}{r}-, 010 \\
, 848\end{array}$ & $\begin{array}{r}206^{* *} \\
, 000 \\
\end{array}$ & $\begin{aligned}, 160^{* *} \\
, 003\end{aligned}$ & 1 & \\
\hline 7-Meaningful work & $\begin{array}{l}\text { Pearson Correlation } \\
\mathrm{p}\end{array}$ & $\begin{array}{r}, 114^{*} \\
, 034 \\
\end{array}$ & $\begin{array}{r}-, 003 \\
, 960\end{array}$ & $\begin{array}{r}, 171^{* *} \\
, 001 \\
\end{array}$ & $\begin{array}{r}, 340^{* *} \\
, 000 \\
\end{array}$ & $\begin{array}{r}, 269^{* *} \\
, 000 \\
\end{array}$ & $\begin{array}{r}, 505^{* *} \\
, 000 \\
\end{array}$ & 1 \\
\hline
\end{tabular}

$\mathrm{N}=348,{ }^{*} \mathrm{p}<.05,{ }^{* *} \mathrm{p}<.01$

When the Table-7 is investigated it can be seen that there is a positive, bi-directional but weak correlation between flexibility and perception of risk and uncertainty at the level of 0.160 **.

\section{Results and Discussion}

In this research, the effect of work experience, age, gender, meaningful work and sturdiness/flexibility, which is among the subscales of psychological capital, on the perception of risk and uncertainty has been investigated. It was determined that age $(p=0.049)$, gender $(p=$ $0.000)$ and work experience $(\mathrm{p}=0.002)$ had influence on the perception of risk an1d uncertainty and the results obtained (Sung and Hanna, 1997) are consistent with the literature. However, the result of our research could not be compared with the literature because no research carried out on either the effects or the relation between the perception of risk and uncertainty and meaningful work $(p=0.000)$ and sturdiness/flexibility $(p=0.785$ and $p>0.05)$ was not found.

Internal control consisting of control environment, risk assessment, control activities, information, communication and follow-up elements is not an objective but a means of administration that bears the aim of reaching an organization to its objectives. It doesn't identify the objectives but provides reasonable assurance in order to achieve the targets which have been set before. Because it is risk-based, it is directly related to organizational stress. It is possible for organizational stress to arise in all organizations, in which a healthy internal control system has not been established, before or during the stage the system is set. Direction, severity and emergence of the organizational stress may vary according to the risks and uncertainties in the processes. The elements out of the organization as well as the individual elements play a role in emergence of organizational stress.

While organizations establish internal control system, they must do it by keeping in mind that it is process that encompasses all activities and is based on the principle of steadiness; not limiting it only to certain points, to certain areas and to certain periods. Throughout the process, strategic steps should be determined by analyzing human source and institutional capacity rather than just planning and filling some standard forms systematically. Institutional competence and capacity should be planned simultaneously and strategic objectives must be realized. 
Bilgen, İ., Yaşar, H., Șeker, M., \& Büyüksivaslığlu, M. N. (2018). Examination of the effects of some variables in internal control and organizational stress management via multiple regression on perception of risk and uncertainty. Journal of Human Sciences, 15(1), 155-162. doi:10.14687/ihs.v15i1.4919

\section{REFERENCES}

Akçay, H. V. (2012). Pozitif Psikolojik Sermayenin İş Tatmini ile İlişkisi. Kahramanmaraş Sütçü Imam Üniversitesi İktisadi ve İdari Bilimler Fakültesi Dergisi,2(1), 123-140.

Akın, A., Hamedoğlu, M., Kaya, C.., Sarıçam, H. (2013). Turkish Version of the Work and Meaning Inventory (WAMI): Validity and reliability study. Journal of European Education, 3(2), 11-16.

Akyel, R. (2010). Yönetimde İç Kontrol, İç Denetim ve Dış Denetim Fonksiyonlarının Birbirleri ile İlişkileri ve Türk Kamu Yönetiminde Uygulanmalarının Değerlendirilmesi. C..Ü. Sosyal Bilimler Enstitüï̈ Dergisi, 19(3), 1-22.

Avey, J. B., Wernsing, T. S., Luthans, F. (2008). Can Positive Employees Help Positive Organizational Change?.Journal Of Applied Behavioral Science, 44(1), 48-70.

Beehr, T. (1998). An Organizational Psychology Meta-Model of Occupational Stress, Theories of Organizational Stress, (Der. Cary L. Cooper). Oxford University Press, 7.

Bayram, N. (2010). Yapısal Eșitlike Modellemesine Giriş. Bursa: Ezgi Kitabevi.

Bilgi, I., Mihaylova, L., Papazov, E. (2017). Internal Control Activities in Small Turkish Companies, Journal of Contemporary Management Issues, 22: 69-83.

Bordia, P.,Jones, E., G., Cindy, C., Victor J.,Difonzo, N.(2006).Management Are Aliens, Rumors and Stress During Organizational Change, Group \& Organization Management,(31): 601-621.

Bossmann, U., Ditzen, B., Schweitzer, C., (2016). Organizational Stress and Dilemma Management in Mid-Level Industrial Executives: An Exploratory Study. Mental HealtherPrevention, 4, 9-18.

Bozkurt, V., Baştürk, Ş. (2009). KOBİ Girişimcilerinde Risk ve Belirsizlik Algılları: Bursa Örneği. Ankara Üniversitesi SBF Dergisi, 64(2), 43-73.

Christina L. S.,Mark C. J. (2003). The Impact of Perceived Organizational Support on the Relationship Between Boundary Spanner Role Stress and Work Outcomes, Journal of Management,19(4): 571.

Cranwell-Ward, J., Abbey, A. (2005). Organizational Stress, MacMillan.

Dickins, D, Fay, R.G. (2017). COSO 2013: Aligning Internal Controls and Principles, Issues in Accounting Education, 32(3): 117-127.

Furedi, F. (2001). Korku Kültürü, Ayrıntı Yayınları, Çev.: B. Yıldırım.

Hall, J. A. (2004). Accounting Information Sytems. International Student Edition, USA: Thomson Corporation. 150.

Hair J.F., W.C. Black, B. J. Babin ve R.E.Anderson. (2010). Multivariate Data Analysis. Pearson.

Leitch, M. (2008). Intelligent Internal Control and Risk Management: Designing High-Performance Risk Control Systems, Gower.

Masten, A., Reed, M.J. "Resilience in Development", in: Rick Synder \&Shane Lopez, (Ed). Handbook of Positive Psychology. Oxford: Oxford University Press, 72-82.

Maureen F. Dollard, Helen R. Winefield, Anthony H. Winefield(2001). Occupational Strainand Efficacy in Human Service Workers, Kluwer Academic Publishers. Boston. 17.

Özdemir Yaylac1, G. (2005). Örgütsel Stresi Yönetmede Etkili Kişilerarası Etkileşim Stratejileri. Amme İdaresi Dergisi, 38(2), 51-59.

Rosso, B. D., Dekas, K. H.,Wrzesniewski, A. (2010). On The Meaning Of Work: A Theoretical Integration And Review. Research in Organizational Behavior, 30, 91-127.

Rumbold, J., Fletcher, D., Daniels K. (2018). Using a mixed method audit to inform organizational stress management interventions in sport. Psychology of Sport \& Exercise, 35, 27-38.

Steger, M. F., Dik, B. J. andDuffy, R. D. (2012). Measuring Meaningful Work: The Work and Meaning Inventory (WAMI). Journal of Career Assessment, 00(0) 1-16.

Sung, J. ve Hanna, S. (1996). Factors Related to Risk Tolerance. Financial Counselling and Planning, 7: 11-20.

Türedi, H., Karakaya, G. (2015). COSO İç Kontrol Modeli ve Kontrol Ortamı. Finans Politik \& Ekonomik Yorumlar, 52(602), 67-76. 
Bilgen, İ., Yaşar, H., Șeker, M., \& Büyüksivaslığlu, M. N. (2018). Examination of the effects of some variables in internal control and organizational stress management via multiple regression on perception of risk and uncertainty. Journal of Human Sciences, 15(1), 155-162. doi:10.14687/ihs.v15i1.4919

Wagnild, G. M.,Young, H. M. (1993). Development and Psychometric Evaluation of The Resiliency Scale. Journal of Nursing Management, 1, 165-178.

Weinberg, A., Sutherland, V.J., Cooper, C. (2010). Organizational Stress Management: A Strategic Approach. MacMillan.

Yankovskaya, A.E., Kornetov, A.N., Il'inskikh, N.N., Obukhovskaya, V.B. (2017). An Expansion of Intelligent Systems Complex for Express-Diagnostics and Prevention of Organizational Stress, Depression, and Deviant Behavior on the Basis of the Biopsychosocial Approach, Pattern Recognition and Image Analysis, 27(4), 783-788.

Yılanc1, M. F. (2003). İs Denetim: Türkiye'nin 500 Büyük Sanayi Issletmesi Üzerine Bir Arastrma. Osmangazi Üniversitesi Basımevi. 34. 